\title{
Postliver transplant allograft reinfection with a lamivudine-resistant strain of hepatitis $B$ virus: Long term follow-up
}

Eric M Yoshida MD FRCPC, Mang M Ma MD FRCPC, Jennifer E Davis BSc MBBS FRCPC, Karl P Fischer MSc, Norman M Kneteman MD FRCSC, Siegfried R Erb MD FRCPC, D Lorne Tyrrell MD PhD FRCPC, Vincent G Bain MD FRCPC

EM Yoshida, MM Ma, JE Davis, et al. Postliver transplant allograft reinfection with a lamivudine-resistant strain of hepatitis B virus: Long term follow-up. Can J Gastroenterol 1998;12(2): 125-129. Lamivudine is a nucleoside analogue with efficacy in the suppression of hepatitis B viral (HBV) replication. In a previously reported study, lamivudine was administered to patients with chronic, actively replicating HBV infection who subsequently underwent liver transplantation. Patients became serum HBV DNA-negative in response to lamivudine before transplantation, which was continued in the post-transplant period. Two of four patients surviving the immediate postoperative period developed allograft reinfection 240 and 409 days post-transplant. The strain of the reinfecting virus was analyzed, and a mutation in the YMDD region of the viral polymerase conferring resistance to lamivudine was discovered. The long term follow-up of these two patients is reported. The first patient developed ascites 16.5 months after allograft reinfection. A transjugular liver biopsy performed 18 months after the emergence of the lamivudine-resistant strain revealed cirrhosis and lobular hepatitis without rejection. The gradient between hepatic vein wedged and free pressures was $13 \mathrm{mmHg}$, consistent with portal hypertension. The second patient, 16 months after allograft reinfection with the lamivudineresistant strain, is without clinical evidence of portal hypertension, although liver enzymes remain elevated. Both patients were given a trial of famciclovir, which did not significantly suppress HBV viremia. In conclusion, lamivudine-resistant HBV strains with the YMDD mutation may have an aggressive clinical course with rapid progression to cirrhosis. Famciclovir did not appear to be an effective rescue agent in these two patients.

Key Words: Allograft, Cirrhosis, Hepatitis B, Lamiundine resistance, Liver, Reinfection, Transplantation, YMDD mutation

\section{Suivi à long terme d'une récidive d'infection} post-transplantation hépatique par une souche du virus de l'hépatite $B$ résistante à la lamivudine

RÉSUMÉ : La lamivudine est un analogue des nucléosides qui supprime efficacement la réplication virale du virus de l'hépatite $B(H B V)$. Dans le cadre d'une étude publiée antérieurement, la lamivudine a été administrée à des patients atteints d'une infection à HBV chronique et active qui ont par la suite subi une transplantation hépatique. Les patients sont devenus séronégatifs à l'égard de l'ADN de l'HBV en réponse à la lamivudine avant la transplantation. Ce traitement a été poursuivi après la transplantation. Deux patients sur quatre ayant survécu à la période postopératoire immédiate ont développé une nouvelle infection de l'allogreffe 240 et 409 jours après l'intervention. La souche du virus a été analysée et on a pu imputer la résistance à la lamivudine à une mutation de la région YMDD de la polymérase virale. Le suivi à long terme de ces deux patients est présenté ici. Le premier a développé de l'ascite 16,5 mois après la nouvelle infection de l'allogreffe; une biopsie hépatique trans-jugulaire effectuée 18 mois

voir page suivante

Departments of Medicine and Pathology, University of British Columbia; the British Columbia Transplant Society, Vancouver, British Columbia; Departments of Medicine, Medical Microbiology $\mathcal{E}$ Immunology, and Surgery, University of Alberta, Edmonton, Alberta Correspondence: Dr Eric M Yoshida, Division of Gastroenterology, Vancouver Hospital and Health Sciences Centre, 3300-950 West 10th

Avenue, Vancouver, British Columbia V5Z 4E3. Telephone 604-875-5862, fax 604-875-5447

Received for publication November 17, 1997. Accepted January 26, 1998 
après l'émergence de la souche résistante à la lamivudine a révélé une cirrhose et une hépatite lobulaire sans rejet. Le gradient entre pression hépatique bloquée et libre a été de $13 \mathrm{~mm} \mathrm{Hg}$, concordant avec une hypertension portale. Six mois après la réinfection de l'allogreffe par la souche résistante à la lamivudine, le deuxième patient ne présente aucun signe clinique d'hypertension portale, bien que ses enzymes hépatiques restent élevées. Les deux patients ont reçu à l'essai du famciclovir, qui n'a pas significativement supprimé la virémie à HBV. En conclusion, des souches d'HBV porteuses de la mutation YMDD résistantes à la lamivudine peuvent provoquer une forte évolution clinique, avec progression rapide vers la cirrhose. Le famciclovir n'a pas semblé d'un grand secours chez ces deux patients.
U ntil recently, patients with chronic hepatitis $B$ virus (HBV) infection were not considered candidates for liver transplantation because of the high risk of allograft reinfection (1) and poor clinical outcome $-48 \%$ five-year survival versus $77 \%$ for primary biliary cirrhosis (2). The use of high dose parenteral HBV immune globulin (HBIG) as prophylaxis against reinfection $(3-5)$ can reduce this risk to a clinically acceptable level, but the economic costs of such a prophylactic program are considerable. It is obvious that an effective form of anti-HBV prophylaxis that does not require HBIG would result in significant cost savings and allow more patients with HBV infection to be offered transplantation.

Lamivudine is a nucleoside analogue that is an effective antiretroviral agent in the treatment of human immunodeficiency virus (HIV) infection (6-8). Lamivudine was initially discovered to be effective in the suppression of active HBV infection in those co-infected with HIV $(9,10)$. Later clinical trials in the non-HIV setting have confirmed the efficacy of lamivudine in suppressing HBV replication $(11,12)$. Lamivudine appears to be a logical choice for prophylaxis against allograft reinfection in the transplant setting. A pilot study in liver transplantation with lamivudine as primary prophylaxis was undertaken at the University of Alberta (UA). It was reported that two of four long term transplant survivors developed allograft reinfection while on lamivudine (13). The reinfecting virus was sequenced and found to contain a point mutation in a specific locus of the polymerase that conferred resistance to lamivudine (14). These two reported patients were among the first to be described with this HBV mutation, of which the natural history has yet to be reported. In this report, we present the long term follow-up of these two previously reported patients.

\section{PATIENTS AND METHODS}

Both patients were previously reported as part of a lamivudine and liver transplantation phase II study (13). The first patient was also reported in a study by Tipples et al (14). Briefly, in accordance with the study protocol (13), both patients with end-stage liver disease secondary to chronic HBV and HBV DNA-positive serum were given lamivudine $100 \mathrm{mg} /$ day orally four to five weeks before transplantation. At the time of transplantation, both patients were serum HBV DNA-negative (less than $5 \mathrm{pg} / \mathrm{mL}$ ) by radiolabelled liquid hybridization assay (Abbott Genostics, Abbott Laboratories, Illinois). Postoperative lamivudine was administered via nasogastric tube at a dose of $300 \mathrm{mg} /$ day, with dose reduction to $100 \mathrm{mg} /$ day when oral administration was commenced. Immunosuppression induction consisted of cyclo- sporine, azathioprine and tapering methylprednisolone. Maintenance immunosuppression consisted of cyclosporine, azathioprine and prednisone tapered over months. Serum HBV surface antigen (HBsAg), HBV surface antibody, HBV early antigen, HBV early antibody and HBV DNA were screened weekly during the initial two months, every two weeks for the next two months and then monthly until the occurrence of HBV allograft reinfection. After allograft reinfection, the frequency of serum HBV DNA testing was determined by clinical need.

Both patients were followed regularly and concurrently at UA and the University of British Columbia (UBC). Serum HBV DNA was measured by radiolabelled liquid hybridization assay (Abbott Genostics) at UA and by chemiluminescent molecular hybridization assay (Digene Hybrid Capture HBV DNA Assay, Maryland) at UBC. Due to the use of different hybridization test kits at the two universities, the measured serum HBV DNA values between centres were not comparable, although a reported conversion is as follows (15):

\section{Digene HBV DNA $(p g / m L)=(7 \times$ Abbott HBV DNA +5) $(\mathrm{pg} / \mathrm{mL})$}

The specific lamivudine-resistant HBV strain was isolated and identified in both patients at UA. The virus polymerase gene was amplified by polymerase chain reaction and the YMDD motif sequenced by methods previously reported (14).

\section{CASE PRESENTATIONS}

Patient 1: A former nursing assistant contracted HBV 10 years before transplantation as a result of a needle-stick injury, with subsequent development of end-stage cirrhosis and portal hypertension. She was 41 years of age at the time of liver transplantation and initially had an uncomplicated post-transplant course with unremarkable liver enzymes. An asymptomatic rise in liver enzymes eight months post-transplantion was investigated and found to be a result of allograft reinfection with HBV. Serum HBV DNA quantified at UA (Abbott) on post-transplant day (PTD) 240 was $465 \mathrm{pg} / \mathrm{mL}$. Serum HBV DNA quantified at UBC (Digene) on PTD 251 was $3659 \mathrm{pg} / \mathrm{mL}$, reflecting the difference in assays between the two centres. The strain of reinfecting HBV was subsequently analyzed (14) and found to contain a mutation in the YMDD motif conferring resistance to lamivudine. The dose of lamivudine was increased to $300 \mathrm{mg} /$ day, with concurrent addition of famciclovir at a dose of $500 \mathrm{mg}$ three times daily and intramuscular administration of HBIG (Abbot Laboratories). Serum HBVHBV DNA (Abbott) declined to $164 \mathrm{pg} / \mathrm{mL}$ on PTD 263 with administration of this antiviral regimen. 


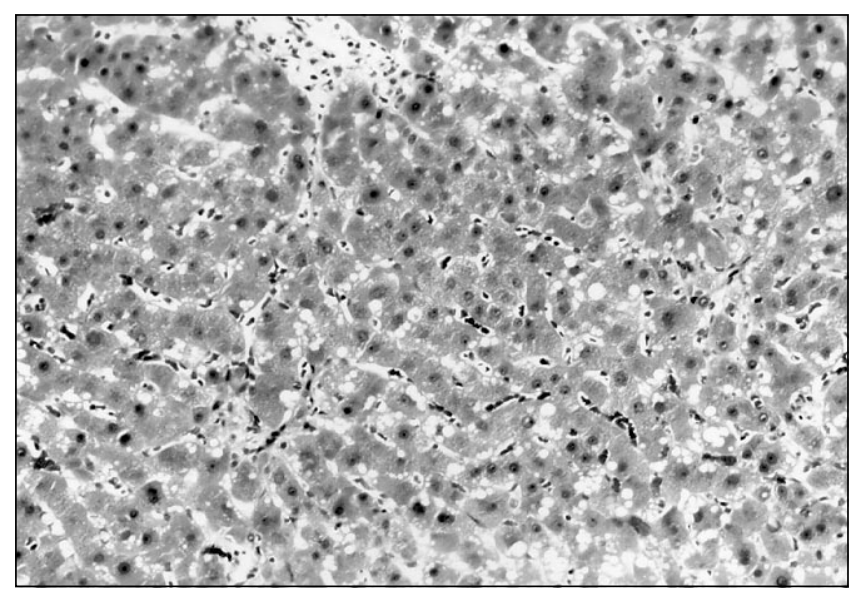

Figure 1) Liver biopsy from patient 1 taken 2.5 months after allograft reinfection with lamivudine-resistant hepatitis $B$ virus revealing mild lobular hepatitis and normal architecture (hematoxylin and eosin, original magnification $\times 40$ )

The liver was biopsied on PTD 314 as the result of a persistent mixed pattern of liver enzyme elevation (PTD 307: aspartate aminotransferase [AST] $61 \mathrm{U} / \mathrm{L}$ [normal less than $40 \mathrm{U} / \mathrm{L}$ ], alanine aminotransferase [ALT] $57 \mathrm{U} / \mathrm{L}$ [normal less than $55 \mathrm{U} / \mathrm{L}$ ], alkaline phosphatase $205 \mathrm{U} / \mathrm{L}$ [normal less than $125 \mathrm{U} / \mathrm{L}$ ], gamma-glutamyltranspeptidase [GGT] $606 \mathrm{U} / \mathrm{L}$ [normal less than $50 \mathrm{U} / \mathrm{L}$ ], total bilirubin $25 \mu \mathrm{mol} / \mathrm{L}$ [normal less than $22 \mu \mathrm{mol} / \mathrm{L}]$ ). Biopsy revealed lobular hepatitis (Figure 1) and acute cellular rejection (mixed portal inflammatory infiltrate, biliary duct damage and endotheliitis). A trichrome stain did not reveal evidence of increased fibrosis. The acute rejection episode was treated with pulse methylprednisolone $(500 \mathrm{mg}$ intravenously daily for three doses).

Elevated liver enzymes subsequently returned to within normal limits by PTD 317. Repeat serum HBV DNA measurements at both centres revealed that levels had increased to 200 to $215 \mathrm{pg} / \mathrm{mL}$ (Abbott) and $6137 \mathrm{pg} / \mathrm{mL}$ (Digene) (PTD 383). Famciclovir was discontinued from the regimen, and HBIG was administered on a regular basis from PTD 376 to 445 . HBsAg remained positive throughout the period of HBIG administration and anti-HBsAg titres were consistently undetectable. Further HBIG administration was discontinued due to lack of efficacy.

The patient's liver enzymes remained consistently within normal limits despite continuation of lamivudine as the sole antiviral agent. Despite unremarkable biochemistry, serum HBV DNA remained elevated, with a level greater than $2000 \mathrm{pg} / \mathrm{mL}$ (Digene) on PTD 527. Except for persistent right upper quadrant discomfort, the patient remained asymptomatic until 14 months after allograft reinfection with the lamivudine-resistant HBV strain. Development of abdominal distention was investigated with ultrasound, which revealed the presence of ascites (PTD 734). A transjugular liver biopsy with hepatic vein pressure measurements was performed on PTD 808. Hepatic vein wedged pressure (HVWP) was $26 \mathrm{mmHg}$, and hepatic vein free pres-

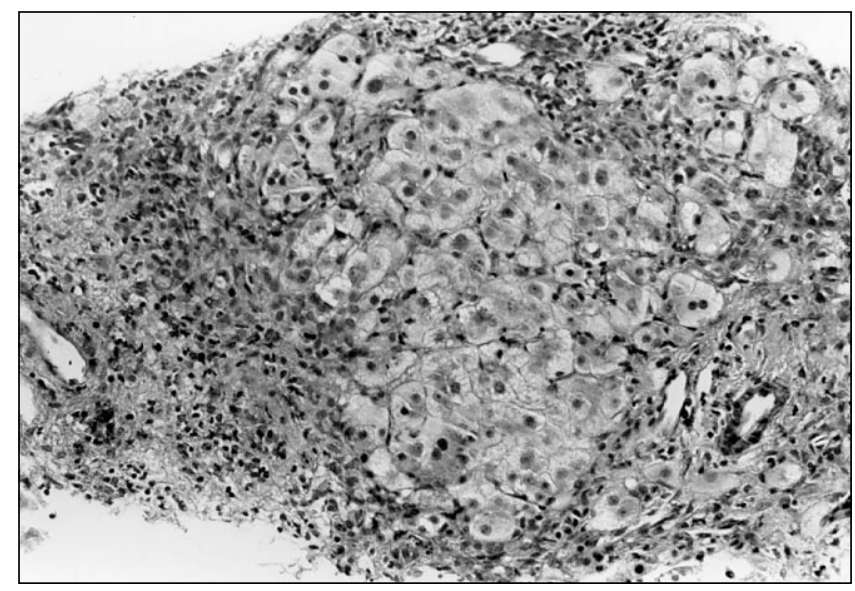

Figure 2) Liver biopsy from patient 1 taken 18 months after allograft reinfection showing cirrhosis with nodule formation and lobular hepatitis with piecemeal necrosis (periodic acid Schiff with distase, original magnification $\times 40$ )

sure (HVFP) was $13 \mathrm{mmHg}$. The HVWP-HVFP gradient was $13 \mathrm{mmHg}$, which was consistent with portal hypertension (normal gradient less than $6 \mathrm{mmHg}$ ) (16). Liver biopsy revealed lobular hepatitis and cirrhosis (Figure 2). There was no evidence of acute or chronic rejection. The patient continues to be maintained on lamivudine.

Patient 2: The second patient was a man who was 55 years of age at the time of transplantation. He had a history of long standing chronic hepatitis, resulting in decompensated cirrhosis. His HBV infection was believed to be the result of vertical transmission. The post-transplant course was unremarkable until PTD 409, when his liver enzymes suddenly increased (peak enzymes PTD 429: AST $275 \mathrm{U} / \mathrm{L}$, ALT $609 \mathrm{U} / \mathrm{L}$, alkaline phosphatase $85 \mathrm{U} / \mathrm{L}$, GGT $80 \mathrm{U} / \mathrm{L}$, total bilirubin $190 \mu \mathrm{mol} / \mathrm{L}$ ). The flare in serum enzymes was accompanied by symptoms of general malaise, nausea and vomiting. A liver biopsy on PTD 415 revealed minimal portal inflammation and moderate focal lobular hepatitis (Figure 3). There was no fibrosis or evidence of rejection. Immediately before the flare in liver enzymes, HBsAg reverted to seropositivity (PTD 393), having been repeatedly negative. Serum HBV DNA (Digene) on PTD 439 was $759.9 \mathrm{pg} / \mathrm{mL}$. The reinfecting virus was subsequently sequenced (at UA) and found to contain a mutation in the YMDD motif.

The dose of lamivudine was increased to $300 \mathrm{mg} /$ day; famciclovir $500 \mathrm{mg}$ three times daily and weekly HBIG injections were added to the antiviral regimen. Symptoms of acute hepatitis resolved after two months. Liver enzymes returned to within normal limits by PTD 481. The enzymes, however, again became elevated to varying degrees shortly thereafter and have remained persistently elevated (PTD 846: ALT $84 \mathrm{U} / \mathrm{L}$, AST $87 \mathrm{U} / \mathrm{L}$, alkaline phosphatase $134 \mathrm{U} / \mathrm{L}$, total bilirubin $15 \mu \mathrm{mol} / \mathrm{L})$. Follow-up serum HBV DNA determinations (Digene) on PTD 457 and PTD 556 were $274.9 \mathrm{pg} / \mathrm{mL}$ and $1628 \mathrm{pg} / \mathrm{mL}$, respectively. HBIG was discontinued three months after initiation due to lack of efficacy. Famciclovir was likewise discontinued after six months. 


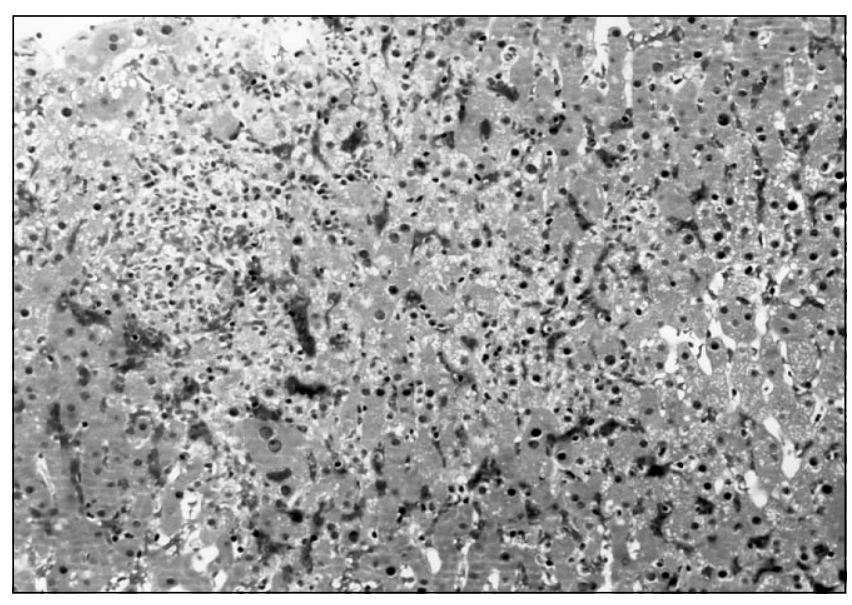

Figure 3) Liver biopsy from patient 2 revealing lobular hepatitis (hematoxylin and eosin, original magnification $\times 40$ )

Sixteen months after allograft reinfection the patient is asymptomatic without clinical evidence of decompensated liver disease and remains on lamivudine.

\section{DISCUSSION}

Although HBV is a DNA virus, its replicative cycle requires RNA-dependent reverse transcription (17) similar to that of retroviruses such as HIV. Lamivudine, an antiretroviral agent, has been demonstrated to be effective in suppressing HBV replication in the nontransplant setting (10-12). The possibility of administering prophylactic lamivudine to liver allograft recipients transplanted because of chronic HBV infection has recently been studied. Aside from the present study (13), which reported only a 50\% recurrence-free success rate in long term survivors, a $90 \%$ success rate of patients surviving the immediate postoperative period $(n=10)$ has also been reported (18). The emergence of lamivudine-resistant strains of HBV was first reported simultaneously by us (14) and investigators in the United Kingdom (19). Since then, other transplant centres have, likewise, reported the emergence of lamivudine-resistance mutations $(20,21)$. The emergence of lamivudine resistance has also been reported in the nontransplant setting (22). Although the incidence of emergence of these strains is not known, based on the patients reported in the literature the rate of development of resistant mutations is estimated to be on the order of $25 \%$ $(13,18,21)$. This estimate, however, is based on very small numbers of study participants and short periods of observation.

To date, the lamivudine-resistant strains of HBV all contain a point mutation in a specific locus of the viral polymerase - the YMDD (tyrosine, methionine, aspartate, aspartate) motif, with isoleucine or valine substituting for methionine $(14,19-22)$. This mutation in the $Y M D D$ region is identical to that identified in lamivudine-resistant strains of HIV (23). Because the YMDD mutation in HBV has only recently been reported, the long term natural history has, to date, not been described. Because no occurrences of fibrosing cholestatic hepatitis, an aggressive and almost al- ways fatal form of allograft reinfection (24), have been reported, some have speculated that the YMDD mutation is less virulent than the wild type of HBV. Our experience suggests that lamivudine escape mutations may, in fact, be quite aggressive. Our first patient developed end-stage cirrhosis with both documented (increased HVWP-HVFP gradient) and clinically apparent portal hypertension (ascites) within 18 months of allograft reinfection with this strain. This patient did not suffer from chronic rejection, and her decompensated cirrhosis can only be attributed to the lamivudine-resistant strain of HBV. Her post-transplant course is similar to that experienced in the pre-lamivudine/HBIG era, with cirrhosis described within a year of transplantation (25).

The clinical course of our second patient has been less severe than that of the first patient. Although the patient was acutely symptomatic during the acute phase of allograft reinfection, these symptoms resolved as the flare of serum aminotransferases subsided. Sixteen months after allograft reinfection with the lamivudine-resistant strain of HBV, he is clinically well without evidence of portal hypertension. It is tempting to speculate that his long term clinical outlook will be favourable and analagous to that of patients with allograft reinfection with hepatitis $\mathrm{C}$ - chronic hepatitis with acceptable long term graft and patient survival (26). It must be noted, however, that this patient continues to have persistently elevated liver enzymes, and his follow-up period is still relatively short. It is too premature to state that the YMDD mutation, in the long term, is less virulent and that this patient's clinical course will continue to remain benign.

An additional point of interest is that both of these patients underwent a therapeutic trial of famciclovir for a significant period of time after the emergence of the lamivudine-resistant strain. Famciclovir is a nucleoside antiviral agent that has demonstrated efficacy in the treatment of herpetic infections (27). Famciclovir is the prodrug of the active compound penciclovir. Famciclovir or penciclovir has been demonstrated to suppress HBV replication in vitro (28) in a Pekin duck model (29) and in a small clinical trial (90\% reduction of serum HBV in six of 11 patients) (30). Famciclovir therapy has also been reported to be of some success in the treatment of post-transplant allograft reinfection with wild-type HBV $(31,32)$. In both of our patients, the addition of famciclovir did not appear to produce any significantly sustained reduction in serum HBV DNA levels. Although our experience with famciclovir and infection with lamivudine-resistant strains of HBV is limited to only two patients, it suggests that the YMDD mutation is not responsive to famciclovir therapy.

\section{CONCLUSIONS}

Our clinical experience with the YMDD-mutated strain of lamivudine-resistant HBV suggests that the strain can be aggressive. The resulting chronic hepatitis may be associated with significant morbidity and result in end-stage cirrhosis within a short period of time. To date, the available antiviral agents have been ineffective in suppressing this mutant strain. 


\section{REFERENCES}

1. Samuel D, Muller R, Alexander G, et al. Liver transplantation in European patients with the hepatitis B surface antigen. N Engl J Med 1993;329:1842-7.

2. Belle SH, Beringer KC, Detre KM, et al. Trends in liver transplantation in the United States. In: Terasaki PI, Cecka JM, eds. Clinical Transplants 1993. California: UCLA Tissue Typing Laboratory, 1994:19-35.

3. Samuel D, Bismuth A, Matthieu D, et al. Passive immunoprophylaxis after liver transplantation in HBsAg-positive patients. Lancet 1991;337:813-5.

4. McGory RW, Ishitani MB, Oliveira WM, et al. Improved outcome of orthotopic liver transplantation for chronic hepatitis B cirrhosis with aggressive passive immunization. Transplantation 1996;61:1358-64

5. Terrault N, Zhou S, Combs C, et al. Prophylaxis in liver transplant recipients using a fixed dosing schedule of hepatitis $B$ immunoglobulin. Hepatology 1996;61:1358-64.

6. Katlama C, Ingrand D, Loveday C, et al. Safety and efficacy of lamivudine-zidovudine combination therapy in antiretroviral-naive patients. A randomized controlled comparison with zidovudine monotherapy. JAMA 1996;276:118-25

7. Staszewski S, Loveday C, Picazo JJ, et al. Safety and efficacy of lamivudine-zidovudine combination therapy in ziduvudineexperienced patients. A randomized controlled comparison with ziduvudine monotherapy. JAMA 1996;276:111-7.

8. Bartlett JA, Benoit SL, Johnson VA, et al. Lamivudine plus ziduvudine compared with zalcitabine plus ziduvudine in patients with HIV infection. A randomized double-blind, placebo-controlled trial. North American HIV working party. Ann Intern Med 1996;125:161-72.

9. Benhamou Y, Dohin E, Lunel-Fabiani F, et al. Efficacy of lamivudine on replication of hepatitis B virus in HIV-infected patients. Lancet 1995;345:396-7. (Lett)

10. Benhamou Y, Katlama C, Lunel F, et al. Effects of lamivudine on replication of hepatitis B virus in HIV-infected men. Ann Intern Med 1996;125:705-12.

11. Dienstag JL, Perillo RP, Schiff ER, et al. A preliminary trial of lamivudine for chronic hepatitis B infection. N Engl J Med 1995;333:1657-61.

12. Lai CL, Ching CK, Tung AK, et al. Lamivudine is effective in suppressing hepatitis B virus DNA in Chinese hepatitis B surface antigen carriers: a placebo controlled trial. Hepatology 1997;25:241-4.

13. Bain VG, Kneteman NM, Ma MM, et al. Efficacy of lamivudine in chronic hepatitis B patients with active viral replication and decompensated cirrhosis undergoing liver transplantation. Transplantation 1996;62:1456-62.

14. Tipples GA, Ma MM, Fischer KP, et al. Mutation in HBV RNAdependant DNA polymerase confers resistence to lamivudine in vivo. Hepatology 1996;24:714-7.

15. De Lamballerie X, Gallian P, De Micco PH. Evaluation of a chemiluminescent molecular hybridization assay for the detection and quantitation of hepatitis B virus-DNA in serum. New Microbiol 1995;18:207-13.
16. Bosch J, Navasa M, Garcia-Pagan JC, Delacy AM, Rhodes J. Portal hypertension. Med Clin North Am 1989;73:931-53.

17. Civitico G, Wang YY, Luscombe C, et al. Antiviral strategies in chronic hepatitis B virus infection II. Infection of duck hepatitis B virus in vitro using conventional antiviral agents and supercoiled-DNA active compounds. J Med Virol 1990;31:90-7.

18. Grellier L, Mutimer D, Ahmed M, et al. Lamivudine prophylaxis against reinfection in liver transplantation for hepatitis B cirrhosis. Lancet 1996;348:1212-5.

19. Ling R, Mutimer D, Ahmed M, et al. Selection of mutations in hepatitis $B$ virus polymerase during therapy of transplant recipients with lamivudine. Hepatology 1996;24:711-3.

20. Bartholomew MM, Jansen RW, Jeffers LJ, et al. Hepatitis B-virus resistance to lamivudine given for recurrent infection after othotopic liver transplantation. Lancet 1997;349:20-2.

21. Perillo R, Rakela J, Martin P, et al. Lamivudine for hepatitis B after liver transplantation (OLT). Hepatology 1996;24:223A.

22. Naoumov NV, Chokshi S, Smith HM, Williams R. Emergence and characterization of lamivudine-resistent hepatitis B virus variant. Hepatology 1996;24:621A.

23. Tisdale M, Kemp SD, Parry NR, Larder BA. Rapid in vitro selection of human immunodeficiency virus type 1 resistant to 3 'thiacytidine inhibitors due to a mutation in the YMDD region of reverse transcriptase. Proc Natl Acad Sci USA 1993;90:5653-6.

24. Davies SE, Portmann BC, O'Grady JG, et al. Hepatic histologic findings after transplantation for chronic hepatitis B virus infection, including a unique pattern of fibrosing cholestatic hepatitis. Hepatology 1991;13:150-7.

25. Demetris HA, Todo S, Van Thiel DH, et al. Evolution of hepatitis B virus liver disease after hepatic replacement. Am J Pathol 1990;137:667-76.

26. Gane EJ, Portmann BC, Naoumov NV, et al. Long term outcome of hepatitis $\mathrm{C}$ infection after liver transplantation. N Engl J Med 1996;334:815-20.

27. Sacks SL, Aoki FY, Diaz-Mitoma F, et al. Famciclovir reduced lesion healing time in recurrent genital herpes. JAMA 1996;276:44-9.

28. Korba BE, Boyd MR. Penciclovir is a selective inhibitor of hepatitis B virus replication in cultured human hepatoblastoma cells. Antimicrob Agents Chemother 1996;40:1282-4.

29. Tsiquaye KN, Sutton D, Maung M, Boyd MR. Antiviral activities and pharmacokinetics of penciclovir and famciclovir in Pekin ducks chronically infected with duck hepatitis B virus. Antiviral Chem Chemother 1996;7:153-9.

30. Main J, Brown JL, Howells C, et al. A double-blind, placebo-controlled study to assess the effect of famciclovir on virus replication in patients with chronic hepatitis B virus infection. J Viral Hepatitis 1996;3:211-5.

31. Kruger M, Tillmann HL, Trautwein C, et al. Famiclovir treatment of hepatitis B virus recurrence after liver transplantation: a pilot study. Liver Transplant Surg 1996;2:253-62.

32. Rabinovitz M, Dodson F, Rakela J. Famciclovir for recurrent hepatitis $\mathrm{B}(\mathrm{HBV})$ infection after liver transplantation (OLTX). Hepatology 1996;24:624A. 


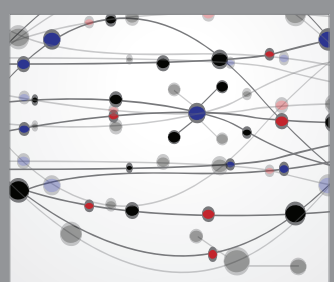

The Scientific World Journal
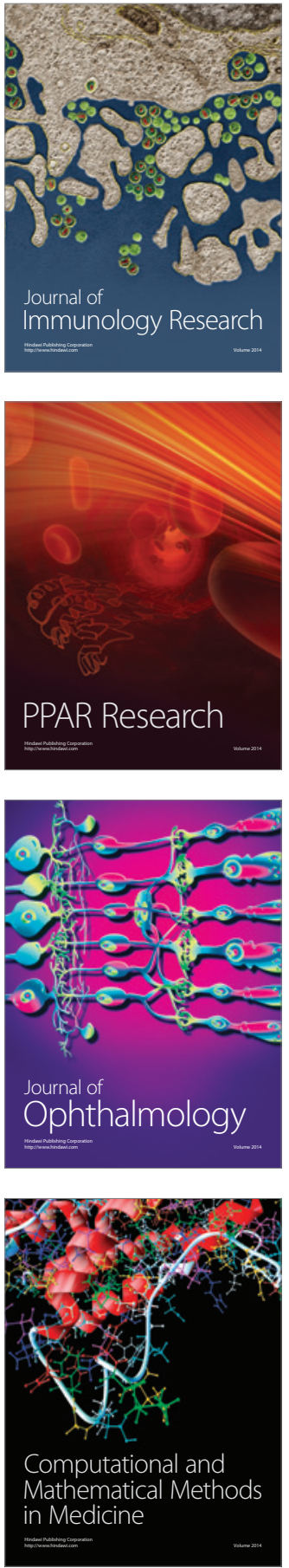

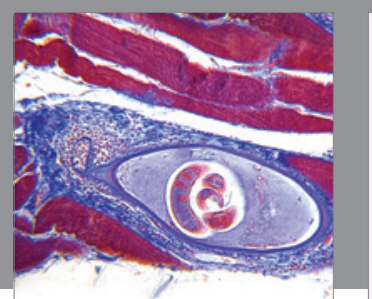

Gastroenterology Research and Practice

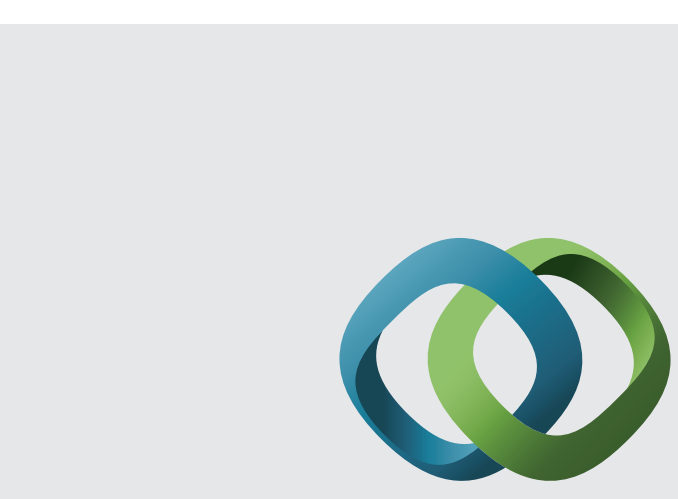

\section{Hindawi}

Submit your manuscripts at

http://www.hindawi.com
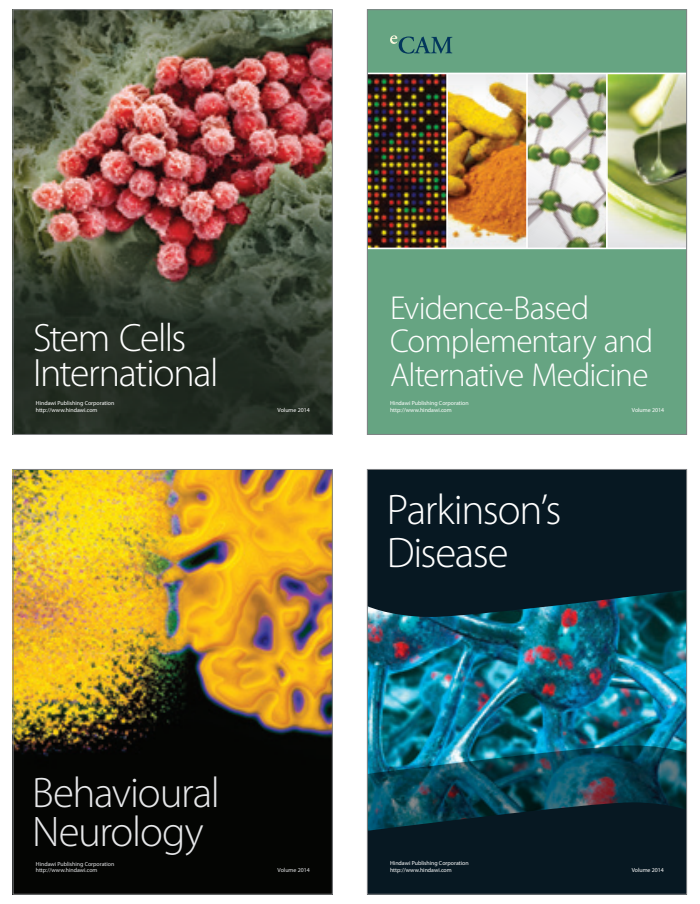
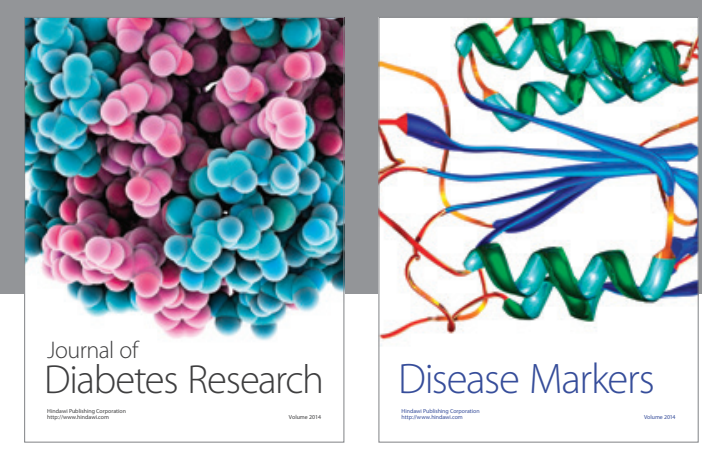

Disease Markers
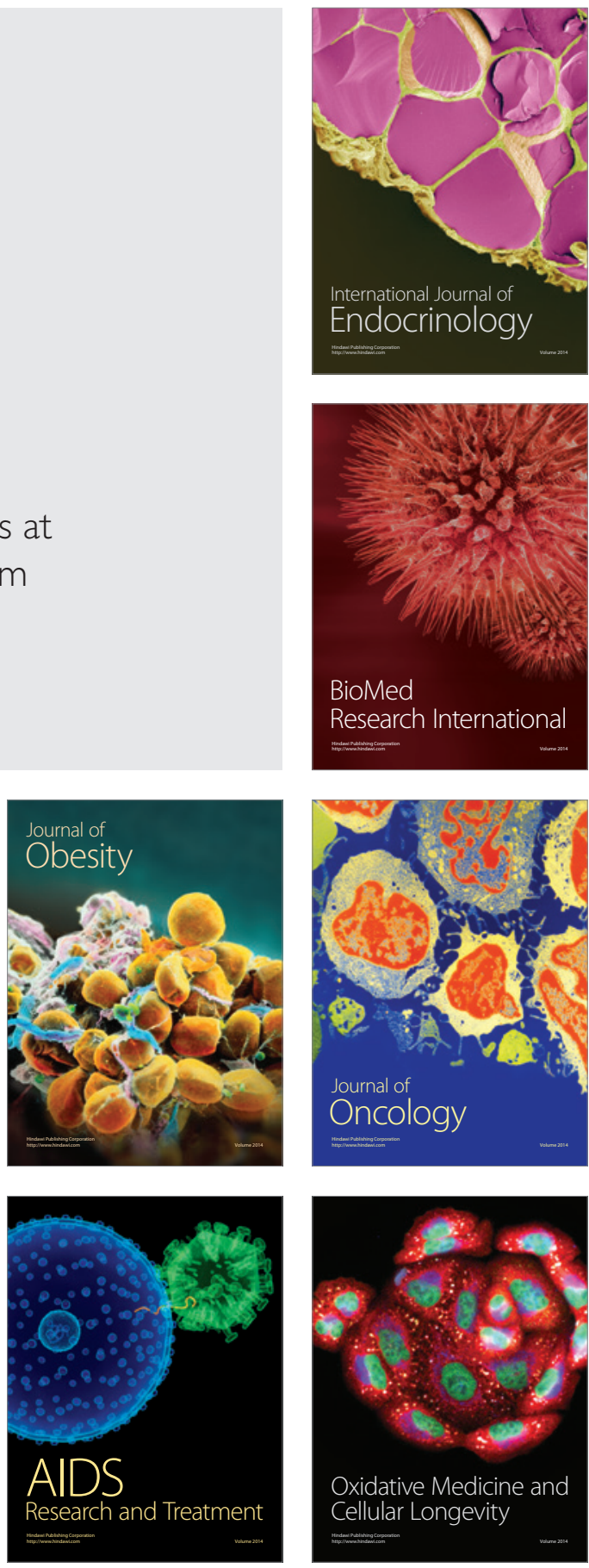